\title{
Ultrastructural analysis of a local regulation of Leydig cells in the adult monkey (Macaca fascicularis) and rat
}

\author{
J. P. Fouquet* \\ Laboratoire de Physiologie de la Reproduction des Vertébrés, Université P\& M Curie, Paris, \\ France
}

\begin{abstract}
Summary. Peritubular Leydig cells located in interstitial areas surrounded by tubules at nearly the same stage of spermatogenesis were analysed. Low-power electron micrographs were used for measurement of cell profile area and higher magnification views provided volume density of SER, Golgi stacks, mitochondria, and lipids. In the adult monkey, no cyclic changes were found in Leydig cells in their size or in the volume density of their organelles. In the adult rat (63 days of age), a comparison limited to stage VII-VIII and stage XI-XII peritubular Leydig cells demonstrated a significantly higher SER content $(P<0.01)$ in the former, but no other differences. The study of subadult rats (45 days of age) showed that the full development of spermatogenesis was required to detect significant changes in Leydig cell SER content. The present results provide morphological evidence for an intratesticular control of the Leydig cells of the rat but not for those of the monkey.
\end{abstract}

\section{Introduction}

It is now widely accepted that gonadotrophic regulation of Leydig cells is modulated by local interactions between the seminiferous tubules and the interstitial tissue (Sharpe, 1983, 1984; Parvinen et al., 1984; Kerr \& Sharpe, 1985; Waites et al., 1985). Sertoli-Leydig cell communications have been demonstrated (Sharpe \& Cooper, 1984; Tabone et al., 1984; Benhamed et al., 1985; Janecki et al., 1985; Verhoeven \& Cailleau, 1985) but the chemical nature of the active substance(s) remains uncertain. In the rat and the stump-tailed macaque, Sertoli cell secretions contain an LHRH-like factor which influences Leydig cell steroidogenesis (Sharpe, 1983, 1984). However, LHRH has no effect on pig Leydig cells (Benhamed et al., 1985). The local control of testicular function might be more complex than expected because macrophage-Leydig cell (Yee \& Hutson, 1985) and peritubular-Sertoli cell interactions (Skinner \& Fritz, 1985) have also been reported.

Bergh $(1982,1983)$ has presented morphometric evidence for the existence of a Leydig cell cycle in the rat testis, this cycle being regulated by the adjacent seminiferous tubules, depending on the stages of the cycle. The changes in Leydig cell size were correlated with cyclic changes in testosterone and androgen-binding protein content of the seminiferous tubules (Parvinen, 1982). The evolution of monkey Leydig cells has been studied morphometrically from birth until sexual maturity (Fouquet et al., 1984) but a possible Leydig cell cycle in the adult monkey was not investigated. The present study was therefore undertaken to correlate Leydig cell ultrastructure with the stages of the seminiferous epithelium cycle in the adjacent tubules in the crab-eating macaque. A limited analysis was also carried out in the rat to re-examine some stage-dependent changes in Leydig cell size previously reported (Bergh, 1982,1983) and to determine whether organelle content was also modified.

\footnotetext{
*Postal address: Laboratoire d'Histologie, U.E.R. Biomédicale des Saints-Pères, 45, rue des Saints-Pères, 75270, Paris cedex 06, France.
} 


\section{Materials and Methods}

Animals. Adult male monkeys (Macaca fascicularis) of proven fertility (5-6 years old) were used. They were raised in captivity, one animal per cage $(\mathrm{N}=4)$ under a natural daylight ratio (Dang, 1977). Male Sprague-Dawley rats were purchased at 6 weeks of age. They were housed two per cage $(\mathrm{N}=8)$ and fed normal diet and water ad libitum until they were killed at 45 or 63 days of age.

Tissue preparation. The monkeys were hemicastrated under sterile conditions after ketamine and thiopentone sodium anaesthesia. As previously described (Fouquet et al., 1984) the testis was infused through the testicular artery with an isotonic saline solution $(9 \mathrm{~g} \mathrm{NaCl} / 1)$ containing heparin and aminocain. The testis was further perfused with a mixture of $2.5 \%$ glutaraldehyde and $2.5 \%$ paraformaldehyde in a $0.1 \mathrm{M}$-cacodylate buffer $\mathrm{pH} 7 \cdot 2$ for $30 \mathrm{~min}$. Transverse slices, through cranial equatorial and caudal portions of each testis, were cut and stored in the fixative for another $2 \mathrm{~h}$. Blocks about $2 \times 2 \times 2 \mathrm{~mm}$ were then cut, post-fixed in $2 \% \mathrm{OsO}_{4}$ for $2 \mathrm{~h}$, dehydrated and embedded in Epon.

The rats were anaesthetized with thiopentone sodium and infused with the saline and fixative solutions described above through the left ventricle of the heart. The testes were then processed as above. Good preservation of tissues was consistently obtained.

Selection of the blocks. The possible influence of the seminiferous tubules on Leydig cells was studied as originally developed by Bergh (1982). Semi-thin sections $(1 \mu \mathrm{m})$ of the different blocks were stained with toluidine blue for light microscope detection of triangular interstitial areas surrounded by 3 tubules which were at nearly the same stage of the seminiferous epithelial cycle. In the monkey, 12 stages were identified (see Clermont, 1972) and the interstitial areas corresponding to 6 different tubular associations (I-II, III-IV, . . XI-XII) were considered. In the adult, as in subadult rats, 14 stages were defined according to Clermont (1972). However, only the interstitial areas surrounded by tubules in stages VII-VIII and XI-XII were considered, taking into account the largest differences in Leydig cell size already shown (Bergh, 1982, 1983). For each type of interstitial area, 3 different blocks per animal were selected giving 9-12 available areas. Thin successive sections were prepared in such a way as to survey a $5 \mu \mathrm{m}$ thickness in each block. These sections were stained with uranyl acetate and lead citrate and observed with a Philips 201 electron microscope for further investigation.

Morphometric analyses. In each selected area, the Leydig cells, which could be defined as peritubular according to Bergh (1983) (cells with a visible nucleus and part of their cytoplasm within $6 \mu \mathrm{m}$ of a specific tubular wall), were systematically analysed by the point-counting method of Weibel et al. (1966). The same transparent overlay bearing a square lattice grid $(0.5 \mathrm{~cm}$ distance between two points) was placed over Leydig cell micrographs obtained at two different magnifications.

Low magnification views $(\times 1470$; enlargement $\times 2)$ were used for counting the number $(n)$ of points over the sections of the Leydig cells showing their nucleus. The cell profile area $\left(\mu \mathrm{m}^{2}\right)$ was derived from $n \times 2.89$ since each point of the grid corresponded to $2.89 \mu^{2}(5000 / 1470 \times 2)^{2}$ with the magnification used. Thus, 25 cells were scored for each type of interstitial area per animal. Then about 30 higher magnification views $(\times 10000$; enlargement $\times 2 \cdot 5)$ of the whole cytoplasm of the same cells in each animal provided the volume density of the organelles directly involved in steroidogenesis: SER (without dictyosomes), mitochondria and lipid droplets. A separate count was also carried out for dictyosomes (Golgi) estimation. The volume density of each component was obtained by counting the points over the relevant structure and dividing by the total number of points over Leydig cell cytoplasm. The number of measurements for each type of interstitial area in each animal was sufficient to achieve sampling adequacy according to Bolender (1978) since the standard error of the mean/mean was $<10 \%$ for Leydig cell profile area and volume density determinations except for lipids.

Statistical analyses. When the mean values obtained for each type of interstitial area in each animal were subjected to an analysis of variance, no significant differences among the adult monkeys were found. Therefore the final values were expressed as the mean ( \pm s.e.m.) of the 4 monkeys (Table 1). The same comparisons were performed for 4 subadult (45 days) and 4 adult (63 days) rats. The final values were expressed as the mean ( \pm s.e.m.) for these two groups of rats except for one subadult animal (Table 2) for which SER volume density was significantly different from that found in the other 3 rats of this age group. A one-way analysis of variance was used to determine significant quantitative differences amongst the various interstitial areas for each group of animals. Further analysis was not necessary.

Figs 1 and 2. Peritubular Leydig cells in an interstitial area surrounded by three stage III tubules in an adult monkey.

Fig. 1. The nucleated Leydig cell (1) is delineated (dotted line) for cell profile area determination. Parts of four other Leydig cells $(2,3,4,5)$ and two macrophages $(M)$ are also indicated. $\times 2940$.

Fig. 2. Volume densities of SER, Golgi, mitochondria and lipids were determined using this higher magnification view of the Leydig cell cytoplasm. $\times 20000$. 

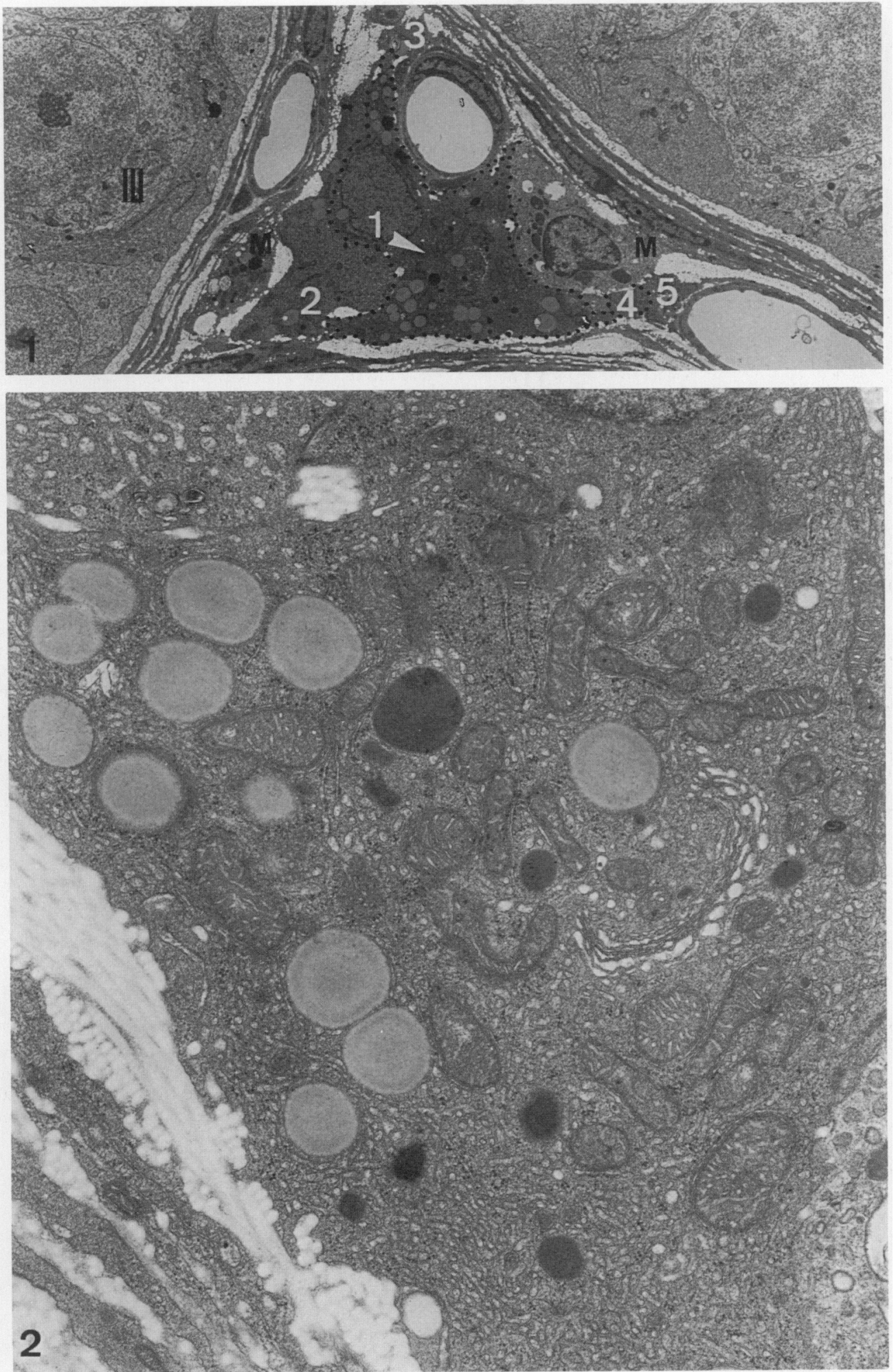

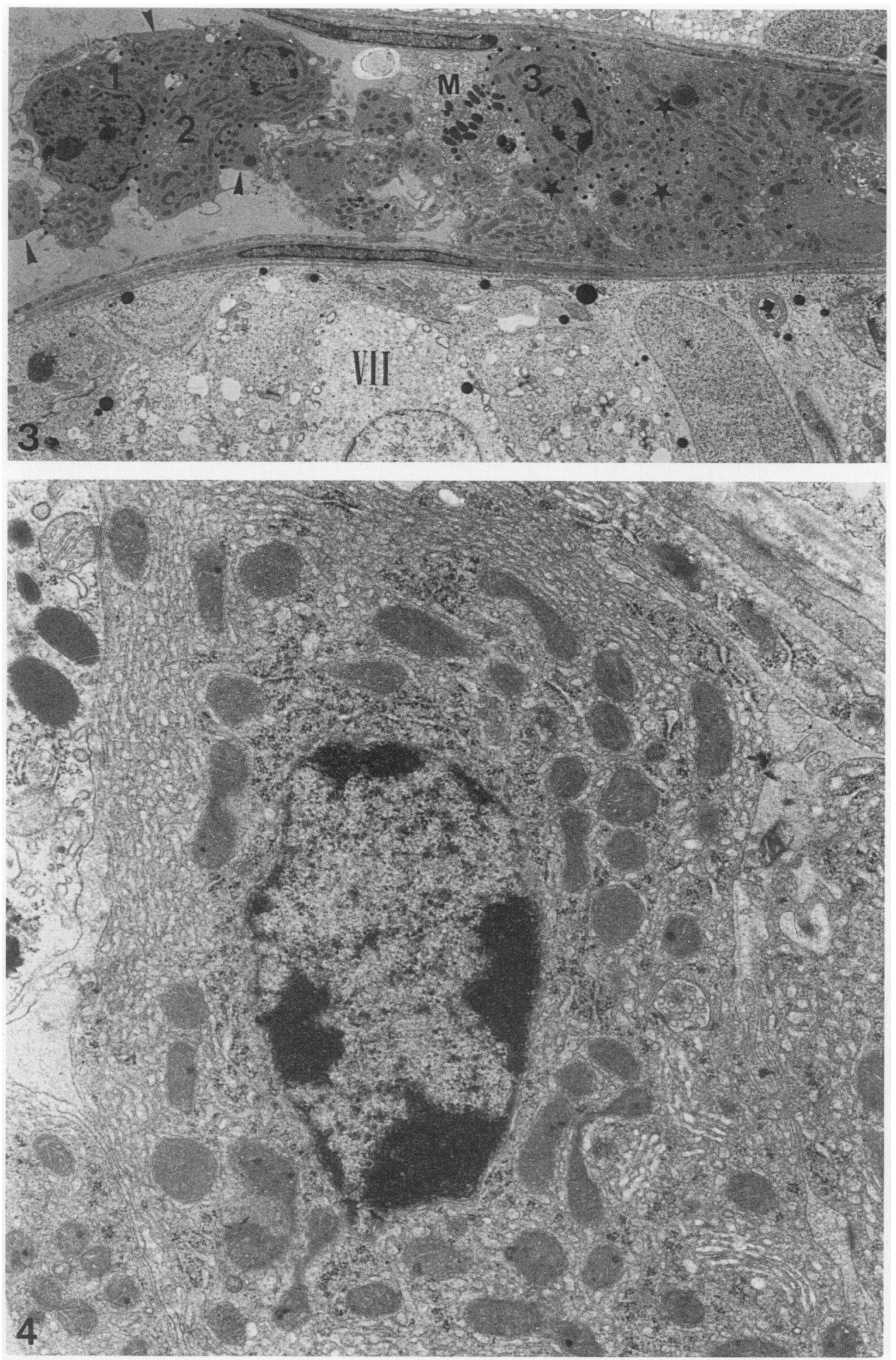


\section{Results}

In the monkeys and rats, Leydig cells were isolated or, more often, clustered in the vicinity of the seminiferous tubules and/or around blood vessels. They were roughly polygonal in shape when viewed with the light microscope but appeared more irregular at the electron microscope level, with extensive processes tightly coupled and/or intermingled. In most cases, the outline of these cells was clearly resolved only after observation of the high-magnification micrographs. Therefore, for the measurements of Leydig cell profile areas on low-magnification micrographs, it was necessary to delimit each cell accurately to avoid counting adjacent cytoplasmic profiles connected to other cells (Figs $1 \& 3$ ). The relationships of these cytoplasmic profiles were clarified after observation of successive sections. Volume densities of SER, Golgi, mitochondria and lipid droplets were easily determined with the higher magnification views (Figs 2 \& 4).

The morphometric analyses performed in the monkey are summarized in Table 1 . Neither Leydig cell profile area nor volume densities of their organelles showed any significant variation according to the stage of the seminiferous epithelial cycle of the adjacent tubules.

Table 1. Morphometry of Leydig cells in 4 adult monkeys

\begin{tabular}{|c|c|c|c|c|c|c|}
\hline \multirow[b]{2}{*}{ Morphometric data } & \multicolumn{6}{|c|}{ Stages of the seminiferous epithelial cycle } \\
\hline & I-II & III-IV & V-VI & VII-VIII & IX-X & XI-XII \\
\hline $\begin{array}{l}\text { Cell profile area } \\
\left(\mu \mathrm{m}^{2}\right)\end{array}$ & $99 \cdot 3 \pm 5 \cdot 6$ & $102 \cdot 3 \pm 4$ & $94 \cdot 8 \pm 4$ & $95 \cdot 4 \pm 3 \cdot 7$ & $92.8 \pm 4.6$ & $92 \cdot 2 \pm 5$ \\
\hline Volume density & & & & & & \\
\hline $\begin{array}{l}\text { Mitochondria } \\
\text { Lipid }\end{array}$ & $\begin{array}{r}19 \cdot 8 \pm 1 \cdot 1 \\
5 \cdot 1 \pm 0.9\end{array}$ & $\begin{array}{r}18.7 \pm 0.3 \\
5.7 \pm 0.6\end{array}$ & $\begin{array}{r}18.9 \pm 0.7 \\
6.4 \pm 0.8\end{array}$ & $\begin{array}{r}18.9 \pm 0.9 \\
5.3 \pm 0.4\end{array}$ & $\begin{array}{r}19 \cdot 4 \pm 1 \cdot 3 \\
5 \cdot 2 \pm 0.3\end{array}$ & $\begin{array}{r}18.1 \pm 0.8 \\
6.0 \pm 0.8\end{array}$ \\
\hline SER & $18 \cdot 5 \pm 1 \cdot 3$ & $20 \cdot 4 \pm 1 \cdot 1$ & $19 \cdot 7 \pm 1$ & $20 \cdot 3 \pm 1 \cdot 6$ & $19 \cdot 3 \pm 1 \cdot 1$ & $19.7 \pm 1.6$ \\
\hline Golgi & $2 \cdot 2 \pm 0.2$ & $2 \cdot 1 \pm 0.2$ & $1 \cdot 9 \pm 0 \cdot 2$ & $2 \cdot 0 \pm 0.2$ & $1.8 \pm 0.2$ & $2 \cdot 2 \pm 0.2$ \\
\hline
\end{tabular}

Results are means \pm s.e.m.; no significant changes could be detected.

In the adult rat (63 days) Leydig cell size and amount of mitochondria, lipid and Golgi stacks did not change significantly but SER content was significantly higher $(P<0.01)$ when the cells adjacent to stage VII-VIII tubules were compared to those adjacent to stage XI-XII tubules (Table 2). In 3 subadult rats (45 days) no significant variations were observed. However, results in one subadult were similar to those in adult animals: stage VII-VIII adjacent Leydig cells contained significantly more SER $(P<0.01)$ than did stage XI-XII adjacent cells. This rat had already completed the first wave of the spermatogenic cycle because numerous step 19 spermatids were observed in stage VIII tubules as well as residual bodies in stage IX tubules. In the other three 45-day-rats, step 19 spermatids were still very few and residual bodies were absent.

Figs 3 and 4. Peritubular Leydig cells in an interstitial area surrounded by two stage VII and one stage VIII tubules in an adult rat.

Fig. 3. The dotted lines emphasize the margin of three nucleated Leydig cells $(1,2,3)$ for cell profile area determination. Surrounding these cells, cytoplasmic profiles of 6 other cells $(-, \star)$ and of one macrophage $(\mathrm{M})$ are also indicated. $\times 2940$.

Fig. 4. This higher magnification view of Leydig cell No. 3 (Fig. 3) is one of the micrographs used for volume density determination of organelles. $\times 20000$. 
Table 2. Morphometry of Leydig cells in rats

\begin{tabular}{|c|c|c|c|c|}
\hline \multirow{2}{*}{$\begin{array}{l}\text { Age } \\
\text { (days) }\end{array}$} & \multirow{2}{*}{$\begin{array}{l}\text { No. of } \\
\text { rats }\end{array}$} & \multirow{2}{*}{$\underset{\text { data }}{\text { Morphometric }}$} & \multicolumn{2}{|c|}{$\begin{array}{l}\text { Stages of the } \\
\text { seminiferous epithelial cycle }\end{array}$} \\
\hline & & & VII-VIII & XI-XII \\
\hline $\begin{array}{l}45 \\
\text { (subadult) }\end{array}$ & 3 & $\begin{array}{l}\text { Cell profile } \\
\text { area }\left(\mu \mathrm{m}^{2}\right) \\
\text { Volume density } \\
\text { Mitochondria } \\
\text { Lipid } \\
\text { SER } \\
\text { Golgi }\end{array}$ & $\begin{array}{r}83.8 \pm 1.9 \\
18.6 \pm 0.6 \\
2.4 \pm 0.3 \\
23.9 \pm 0.4 \\
2.1 \pm 0.2\end{array}$ & $\begin{aligned} 75 \cdot 3 & \pm 4 \cdot 3 \\
& \\
17 \cdot 1 & \pm 1 \\
2 \cdot 1 & \pm 0 \cdot 5 \\
21 \cdot 8 & \pm 0 \cdot 4 \\
2 \cdot 3 & \pm 0 \cdot 2\end{aligned}$ \\
\hline $\begin{array}{l}45 \\
\text { (subadult) }\end{array}$ & 1 & $\begin{array}{l}\text { Cell profile } \\
\text { area }\left(\mu \mathrm{m}^{2}\right) \\
\text { Volume density } \\
\text { Mitochondria } \\
\text { Lipid } \\
\text { SER } \\
\text { Golgi }\end{array}$ & $\begin{array}{c}86.8 \pm 8.4 \\
16.4 \pm 0.8 \\
2.3 \pm 0.4 \\
32.7 \pm 3^{*} \\
2.4 \pm 0.2\end{array}$ & $\begin{array}{c}83 \cdot 2 \pm 4 \cdot 5 \\
18 \cdot 6 \pm 1 \cdot 2 \\
1 \cdot 7 \pm 0 \cdot 3 \\
21 \cdot 6 \pm 2 \\
2 \cdot 2 \pm 0 \cdot 2\end{array}$ \\
\hline $\begin{array}{l}63 \\
\text { (adult) }\end{array}$ & 4 & $\begin{array}{l}\text { Cell profile } \\
\text { area }\left(\mu \mathrm{m}^{2}\right) \\
\text { Volume density } \\
\text { Mitochondria } \\
\text { Lipid } \\
\text { SER } \\
\text { Golgi }\end{array}$ & $\begin{array}{l}78.6 \pm 2 \\
17.0 \pm 1.5 \\
0.5 \pm 0.2 \dagger \\
29.6 \pm 1.4^{* *} \\
2.5 \pm 0.2\end{array}$ & $\begin{array}{r}73 \cdot 7 \pm 3 \cdot 4 \\
17 \cdot 4 \pm 1 \cdot 6 \\
0 \cdot 8 \pm 0 \cdot 3 \\
19 \cdot 7 \pm 0 \cdot 8 \\
2 \cdot 2 \pm 0.2\end{array}$ \\
\hline
\end{tabular}

Results are means \pm s.e.m.

${ }^{*} P<0.01$ compared with value for the other 3 subadult rats.

${ }^{* *} P<0.01$ compared with value for stages XI-XII in adult rats.

$\dagger P<0.02$ compared with values for stages VII-VIII in subadult rats.

\section{Discussion}

The results reported here for the monkey do not show any evidence for a Leydig cell cycle, either in their size or in the volume densities of the organelles involved in the steroidogenic activity and in Golgi content. The values were similar to those previously reported after random analysis of Leydig cells (Fouquet et al., 1984).

In the adult rat, Bergh $(1982,1983,1985)$ and Bergh \& Damber (1984) repeatedly found, in semi-thin sections, cyclic changes in the peritubular Leydig cells with the largest adjacent to stage VII-VIII tubules and the smallest adjacent to stage XI-XII. In the present work, no significant differences in Leydig cell size were observed at the same stages. The reason for these different results is unclear but they may be related to preparative and counting methods. In the present study the estimation of cell profile area in semi-thin sections was not considered valid because most Leydig cells were so closely packed that their outline could not be reliably identified at the light microscope level. Low-power electron micrographs and verification with higher magnification views were necessary to obtain adequate measurements.

Although the size of Leydig cells in the adult rat did not seem to vary in this investigation, the SER volume density was significantly higher at stages VII-VIII than at stages XI-XII. Similar differences in SER amount were not found in subadult rats except for the animal that had already completed the first wave of the spermatogenic cycle. Leydig cell profile area was similar in the two groups of rats.

The values obtained here for volume density of mitochondria, Golgi stacks and lipids compare favourably with those of Mori \& Christensen (1980) and Zirkin et al. (1980) from random analysis 
of rat Leydig cells but intermediate values were found for SER. These different SER estimations may originate from differences in preparative methods, criteria in SER identification and data uncorrected for section thickness. For example, with the fixation used in this study the cytoplasmic matrix was denser than after other fixatives (Mori \& Christensen, 1980) but the contrast was sufficient for counting membranous organelles which were usually identified unambiguously. In the present work some cisternae bearing a few ribosomes on one face only were included in SER counts but Golgi stacks were counted separately. Even if some cisternae or vesicles occurring in the Golgi area were sometimes difficult to distinguish from the SER, the cytoplasmic area including the Golgi components constitute at most $2-2 \cdot 5 \%$ of the cytoplasmic volume. This means that any involvement of Golgi membranes in the SER counts cannot greatly alter the significant differences reported above. Although these morphometric data should not be taken as absolute values, their comparison is valid since the preparative and counting methods used in this study were consistent for all animals and all Leydig cells examined.

The existence of a stage-specific paracrine regulation of Leydig cells by the adjacent seminiferous tubules in the adult rat has been extensively discussed by Bergh (1982, 1983, 1985). His assumption was based on changes in the size of peritubular Leydig cells. 'Similar variations were not noted here but the significant differences in SER amount found at two different specific stages are consistent with the previous interpretation. First, the relationship between the steroidogenic ability of Leydig cells and their SER content has been largely demonstrated (Ewing \& Zirkin, 1983). Secondly, the endogenous tubular testosterone concentration is significantly higher at stage VIII than at any other stage, suggesting that this stage may be particularly dependent on androgen stimulation (Parvinen, 1982). If a stage-specific control of Leydig cells by the seminiferous tubules actually exists, changes in their ultrastructure, at least their SER content, are not surprising. However, this investigation was limited to two different stages; accordingly, more extensive analyses are required before any correlation can be firmly demonstrated. Bergh (1983) stated that perivascular Leydig cells which are not in the close vicinity of the seminiferous tubules are not subjected to local control, unlike peritubular cells. It remains to be seen whether these two types of Leydig cells differ in their size and SER content. From preliminary observations in the monkey and rat this appeared unlikely. In fact, a strict distinction between peritubular and perivascular Leydig cells is somewhat arbitrary because these two cell types are often clustered and joined together with gap junctions suggesting their functional coupling. Furthermore, in the monkey, the interstitial areas are much smaller than in the rat and so most Leydig cells are both peritubular and perivascular.

The fact that cyclic changes were not found in monkey Leydig cells could indicate that a local control may not occur in this species. However, if the seminiferous tubules induce any functional changes in the Leydig cells, which in turn would give rise to morphological variations, these events are certainly time-dependent. Fouquet \& Dadoune (1986) have calculated that the duration of stages V-VI in the monkey is $40 \mathrm{~h}$ whereas in the Sprague-Dawley rat the equivalent stages (VIIVIII) last $85 \mathrm{~h}$ (calculated from data in Clermont, 1972). This time difference may explain, at least in part, why SER changes were observed only in rat Leydig cells: specific morphological modifications in monkey Leydig cells may not have been observed in this study. However, even if a local control of Leydig cells cannot be excluded, the monkey does not seem to be a good model for further investigations.

I thank Mrs Septier for skilful technical assistance; Mr Gouzy for photography; and Mr Reams for checking the MS.

\section{References}

Benhamed, M., Reventos, J., Tabone, E. \& Saez, J.M. (1985) Cultured Sertoli cell-mediated FSH stimulatory effect on Leydig cell steroidogenesis. Am. J. Physiol. 248, E176-E181.
Bergh, A. (1982) Local differences in Leydig cell morphology in the adult rat testis: evidence for a local control of Leydig cell by adjacent seminiferous tubules. Int. J. Androl. 5, 325-330. 
Bergh, A. (1983) Paracrine regulation of Leydig cells by the seminiferous tubules. Int. J. Androl. 6, 57-65.

Bergh, A. (1985) Development of stage-specific paracrine regulation of Leydig cells by the seminiferous tubules. Int. J. Androl. 8, 8085.

Bergh, A. \& Damber, J.-E. (1984) Local regulation of Leydig cells by the seminiferous tubules. Effect of short-term cryptorchidism. Int. J. Androl. 7, 409-418.

Bolender, R.P. (1978) Correlation of morphometry and stereology with biochemical analysis of cell fractions. Int. Rev. Cytol. 55, 247-289.

Clermont, Y. (1972) Kinetics of spermatogenesis in mammals: seminiferous epithelium cycle and spermatogonial renewal. Physiol. Rev. 52, 198-236.

Dang, D.-C. (1977) Resumption of menstruation and fertility after caesarian in Macaca fascicularis. Annls Biol. anim. Biochem. Biophys. 17, 325-329.

Ewing, L.L. \& Zirkin, B. (1983) Leydig cell structure and steroidogenic function. Recent Prog. Horm. Res. 39, 599-635.

Fouquet, J.-P. \& Dadoune, J.-P. (1986) Renewal of spermatogonia in the monkey (Macaca fascicularis). Biol. Reprod. 35, 199-207.

Fouquet, J.-P., Meusy-Dessolle, N. \& Dang, D.-C. (1984) Relationship between Leydig cell morphometry and plasma testosterone during postnatal development in the monkey, Macaca fascicularis. Reprod. Nutr. Develop. 24, 281-296.

Janecki, A., Jakubowiak, A. \& Lukaszyk, A. (1985) Stimulatory effect of Sertoli cell secretory products on testosterone secretion by purified Leydig cells in primary culture. Molec. cell. Endocr. 42, 235-243.

Kerr, J.B. \& Sharpe, R.M. (1985) Follicle stimulating hormone induction of Leydig cell maturation. Endocrinology 116, 2592-2604.

Mori, H. \& Christensen, A.K. (1980) Morphometric analysis of Leydig cells in normal rat testis. J. Cell Biol. 84, 340-354.

Parvinen, M. (1982) Regulation of the seminiferous epithelium. Endocr. Rev. 3, 404-417.

Parvinen, M., Nikula, H. \& Huhtamiemi, I. (1984) Influence of rat seminiferous tubules on Leydig cell testosterone production in vitro. Molec. cell. Endocr. 37, 331-336.

Sharpe, R.M. (1983) Local control of testicular function. Q. Jl exp. Physiol. 68, 265-287.

Sharpe, R.M. (1984) Intratesticular factors controlling testicular function. Biol. Reprod. 30, 29-49.

Sharpe, R.M. \& Cooper, I. (1984) Intratesticular secretion of a factor(s) with major stimulatory effects on Leydig cell testosterone secretion in vitro. Molec. cell. Endocr. 37, 159-168.

Skinner, M.K. \& Fritz, I.B. (1985) Testicular peritubular cells secrete a protein under androgen control that modulates Sertoli cell functions. Proc. natn. Acad. Sci. U.S.A. 82, 114-118.

Tabone, E., Benhamed, M., Reventos, J. \& Saez, J.M. (1984) Interactions between immature porcine Leydig and Sertoli cells in vitro. An ultrastructural and biochemical study. Cell Tissue Res. 237, 357-362.

Verhoeven, G. \& Cailleau, J. (1985) A factor in spent media from Sertoli-cell enriched cultures that stimulates steroidogenesis in Leydig cells. Molec. cell. Endocr. 40, 57-68.

Waites, G.M.H., Speight, A.C. \& Jenkins, N. (1985) The functional maturation of the Sertoli cell and Leydig cell in the mammalian testis. J. Reprod. Fert. 75, 317-326.

Weibel, E.R., Kistler, G.S. \& Scherle, W.F. (1966) Practical stereological methods for morphometric cytology. J. Cell Biol. 30, 23-38.

Yee, J.B. \& Hutson, J.C. (1985) Effects of testicular macrophage-conditioned medium on Leydig cells in culture. Endocrinology 116, 2682-2684.

Zirkin, B.R., Ewing, L.L., Kromann, N. \& Cochran, R.C. (1980) Testosterone secretion by rat, rabbit, guinea pig, dog and hamster testis perfused in vitro: correlation with Leydig cell ultrastructure. Endocrinology 107, 1867-1874. 